December 2011

\title{
Critique of Current Genocide Studies
}

Robert Melson

Follow this and additional works at: https://digitalcommons.usf.edu/gsp

\section{Recommended Citation}

Melson, Robert (2011) "Critique of Current Genocide Studies," Genocide Studies and Prevention: An International Journal: Vol. 6: Iss. 3: Article 9.

Available at: https://digitalcommons.usf.edu/gsp/vol6/iss3/9

This Articles is brought to you for free and open access by the Open Access Journals at Digital Commons @ University of South Florida. It has been accepted for inclusion in Genocide Studies and Prevention: An International Journal by an authorized editor of Digital Commons @ University of South Florida. For more information, please contact digitalcommons@usf.edu. 


\title{
Critique of Current Genocide Studies
}

\author{
Robert Melson \\ Purdue University
}

The present article critiques the views that (1) modern genocide does not substantially differ from its historical predecessors, (2) that all genocide is a product of imperialism, and (3) that the study of genocide can be reduced to a study of perpetrators and collaborators, while the testimonies of victims and survivors need not be taken into account. In contrast, this article suggests (1) that there are significant differences between modern or contemporary genocide and the mass murders of the past, (2) that there is no single explanation for genocide since there are different types of genocide that require separate explanations, and (3) that the testimonies of victims and survivors must be taken into account in order to better understand the motives of the perpetrators and bystanders and give victims and survivors a voice in the narrative of destruction.

Key words: modern genocide, imperialism and genocide, victim and survivor testimonies

Raphael Lemkin initiated the field of genocide studies in large part as a response to the Armenian Genocide of the First World War and the Holocaust of the Second World War. Judging from membership to the International Association of Genocide Scholars (IAGS) and other associations like it, such as the International Network of Genocide Scholars (INoGS), there are today hundreds of genocide scholars working in many fields of knowledge. A main reason for all of this activity is that genocide did not end with the Holocaust and other mass murders of the Second World War. To the contrary, with the emergence of the "third world" and the break-up of the Communist world, instances of genocide have proliferated. Genocide scholars, working in many areas, want to know what explains all the violence and how it can be prevented.

The editors of this special issue have asked us to critique genocide studies as it currently stands and to provide some suggestions to strengthen it. Given the complexity and rich variety of the field, it is difficult to give a detailed assessment of the whole. To facilitate my task I have narrowed my comments to three problem areas. In what follows I critique the following views: (1) modern genocide does not substantially differ from its historical predecessors, (2) all genocide is a byproduct of imperialism, and (3) the study of genocide boils down to a study of perpetrators and collaborators while the testimony of victims and survivors-except insofar as they lend color to the narrative-need not be taken into account.

My primary suggestions are (1) that we need to be more aware of the difference between modern or contemporary genocide and the mass murders of the past, (2) that we resist the temptation to come up with a single explanation for genocide since there are different types of genocide that may require separate explanations, and (3) that we should integrate the testimonies of victims and survivors into our accounts, in part to better understand the motives and behavior of the perpetrators, 
but also to give victims and survivors a voice in the narrative of destruction-a voice that the perpetrators intended to silence.

\section{Modern Genocide}

Massacre, ethnic cleansing, and genocide are not limited to our own times. ${ }^{1}$ Throughout history, populations were wiped out as part of invasion, war, imperialism, and colonialism. The victims were usually foreigners, viewed as external enemies of the state and stigmatized as "barbarians" or "savages." However, in our own times what was rare in the past has become common. In modern genocide, some states perpetrated mass murder by turning against communal groups within their own borders. Entire ethnic, religious, or racial categories that had once been viewed as belonging to the community were annihilated as a planned final solution to a supposed political problem or in pursuit of a bizarre ideological vision. This is what makes modern genocide different from its historical predecessors and also makes it so puzzling.

During the twentieth and twenty-first centuries the world experienced four tidal waves of national and ethnic conflict and modern genocide in the wake of collapsing states and empires. These were punctuated by the First and Second World Wars and by the postcolonial and post-Communist eras. During the First World War and its aftermath, the Ottoman Empire collapsed and committed the first total genocide of the twentieth century against its Armenian minority. In the same period, the disintegration of the German and Austro-Hungarian empires set off nationalist and fascist movements that repressed minorities and precipitated the Second World War. In the context of that war, the Nazis attempted to exterminate Jews and Gypsies and committed partial genocide against other peoples. Following the Second World War, as former European colonial empires-notably Britain and France-withdrew from their possessions, they left behind fragile regimes that lacked legitimacy. Such "third-world" governments frequently ruled over culturally plural societies and tried to impose the hegemony of one ethnic group over the rest. In reaction, minorities rebelled and sought self-determination. This led to ethnic wars and genocide in places like Indonesia, Rwanda, Burundi, Sri Lanka, Nigeria, Pakistan, Ethiopia, Sudan, and Iraq. In the wake of the collapse of Communist regimes in the Soviet Union and former Yugoslavia, the world witnessed the fourth wave of nationalist upsurge, ethnic conflicts, and genocide. Meanwhile, in Africa and elsewhere, the third wave of postcolonial genocide has not yet spent its force.

In the past, empires were culturally plural (think of the Hapsburg and Ottoman Empires) but they were either unconcerned with deriving their legitimacy from those whom they governed or they derived it from God. At times the emperor was viewed as a god. Such empires could be brutal and murderous, but they were likely to practice mass murder and genocide against "barbarians" or "savages" who opposed their rule, not against peoples who had submitted to their rule. That kind of destruction seems to have been invented for our more modern, "enlightened" and democratic era.

What is it about the modern world that makes it so conducive to genocide? I would suggest that most modern states are both culturally plural and derive their legitimacy in some ways from the peoples whom they govern. Both can be preconditions for genocide. In stable democracies genocide against domestic groups is unlikely. Nevertheless, starting with the Athenian destruction of Melos in 416 BCE, stable democracies are perfectly capable of committing genocide abroad or of supporting genocidal regimes as the United States did in Guatemala and elsewhere 
during the Cold War. However, stable democracies are unlikely to exterminate their own citizens, unlike contemporary failed or revolutionary states. ${ }^{2}$

When a contemporary government needs to derive its legitimacy from a culturally plural society in a failed democracy like Weimar Germany, Ottoman Turkey under the Young Turks, or a failed communist state like Yugoslavia after Tito, it is apt to identify only a subset of the ethnically or racially plural society as constituting "the real Germans," "the real Turks," "the real Serbs," or, for that matter, "the real Rwandans" in Rwanda after 1959. The "others" are labeled as "minorities," not quite constituting the "real people," even if they are legally citizens. Such divisions-often deepened and even created by democratic elections-can lead to violence, but they need not yet become catastrophic. They can become so if and when those who are stigmatized as not constituting "the real people" become identified as internal enemies in alliance with the states' external mortal foes in wartime. It is then that internal problems become ripe for "final solutions."

The field of genocide studies might want to pay greater attention to what makes democracies and other states fail, starting with the early Turkish parliamentary failure preceding the First World War and the democratic Weimar Germany preceding the Second World War. Such starting points would avoid reducing the causes of genocide to cultural variables. It was not Ottoman culture or Islam that created the Committee of Union and Progress; nor was it nineteenth-century German anti-Semitism alone that produced the Nazis.

\section{Imperialism and Genocide}

Some leading contemporary scholars of genocide, such as Donald Bloxham, Alexander Hinton, and A. Dirk Moses, have turned to imperialism as a framework for the analysis of contemporary genocide, including the Holocaust. A representative statement of this approach is Moses's important essay "Empire, Colony, Genocide: Keywords and the Philosophy of History," which appears as an introduction to an edited volume that was recently published. ${ }^{3}$

The main thesis of the essay and the book in which it appears, Empire, Colony, and Genocide: Conquest, Occupation, and Subaltern Resistance in World History, is that genocide is a product of colonialism and imperialism, and Moses approvingly discusses Raphael Lemkin's contention that "genocides are intrinsically colonial and that they long precede the twentieth century. The history of genocide is the history of human society since antiquity." 4 Indeed, colonialism and imperialism have been implicated in genocide since antiquity and through the early and later modern eras. One can readily think of many examples from antiquity, such as the conquest of Canaan by the Israelites, the destruction of ancient Israel by Assyria, the destruction of Melos by Athens, and the destruction of Judea and Carthage by Rome. Furthermore, the Spanish conquest of the New World and the European colonization of North America precipitated a demographic disaster for indigenous peoples. The depopulation of the New World, including North America, was in large part caused by the spread of diseases such as smallpox and settler-promoted ethnic cleansing and genocide on a continental scale. At approximately the same time, the British settlement of Australia and New Zealand had similar effects on the native peoples of those regions. In the nineteenth century, Belgium's King Leopold II and his agents' barbaric exploitation of the Congo-verging on genocide-and German imperial massacres of the Herero and Nama were but episodes in the European "Scramble for Africa." 
These were all instances of conquest and colonialism, conducted under imperial regimes, leading to mass destruction and genocide. However, the strong argument claiming that genocide is always a byproduct of colonialism and imperialism presents at least three problems. First, there are many instances of colonialism and imperialism that did not lead to genocide; second, there are important cases, such as the destruction of the European Jews and Roma that were occasioned by Nazi imperialism but had their origins in other historical and ideological sources; and third, as noted above, the claim neglects a major cause of genocide in the modern postcolonial world, namely ethnic nationalism and the failed democratic state. Most of the states that inherited colonial rule governed culturally plural societies, while trying to base their legitimacy on majority support. This promoted ethnically based conflicts over power, leading to failed democracies and genocide in Asia and Africa.

British imperialism and colonialism can certainly be implicated in the physical and cultural destruction of native peoples in North America, Australia, and New Zealand, but the same argument cannot be made for large swathes of British West or East Africa or India. British colonialism was violently imposed and even imposed through massacre, as in India at Amritsar. It cannot be argued, however, that the British practiced wide-scale genocide in their other colonies. Nigeria under indirect rule (1860-1960), for example, did not experience genocide. Massive violence during the Biafran War (1967-1970), especially against the Igbo, occurred after independence from Britain and after the Nigerian nationalist movement took power and splintered along ethnic lines. Significantly, the Biafran crisis developed after the national elections of 1966 .

Nazi imperialism in Eastern Europe and Russia provided the context and the cause for the partial genocide, ethnic cleansing, and enslavement of the indigenous Slavic peoples. The East was designated as the area for Lebensraum and German racial expansion, and its Slavic peoples, especially the Poles and Russians, were deemed to be natives who were expendable and destined for slavery in a future German imperium. However, the Nazis did not view the Jews as natives whose lands and labor could be exploited; they viewed Jews as their supreme racial enemies who were destined for extermination. Indeed, when the Jews of Lodz calculated that they might be able to survive by becoming useful slave workers for the Wehrmacht they were nevertheless deported to Auschwitz. By the same token, the Nazis viewed the Roma as racial undesirables, better exterminated or sterilized than employed. ${ }^{5}$ War and imperialism certainly provided opportunities to expand Nazi extermination policies to Jews and Roma, but such policies had their roots in anti-Semitism and racism that had origins independent from Nazi imperialism, and it is those originsthe pariah status of Jews dating to the Middle Ages, for example-that are overlooked in Empire, Colony, and Genocide.

Moses, in his introductory essay, and Furber and Lower in their chapter are aware of this distinction between Nazi views of Jews and Roma and Nazi views of Russians and Poles, but the authors try to preserve imperialism as the primary cause of genocide even in these instances by arguing that the Nazis viewed themselves as a form of subaltern resistance to Jewish imperialism. ${ }^{6}$ According to this thesis, the Nazis viewed the Jews as colonizers who threatened Germany with extinction. That the Nazis held a bizarre conception of Jews is not in question. The question rather is, Can the Nazis be conceived as a form of subaltern resistance?

To express their hatred of Jews, Nazis relied on a mix of metaphors. The Jews were said to be "maggots in a rotting corpse," "a plague akin to the Black Death," "a parasite sucking the blood of Germany," "a cancer in Germany's body" that had 
to be excised in order for Germany to live, and so on. Jews were also portrayed as agents of capitalist exploitation and Communist subversion, and the Nazis saw themselves as the leaders of an exploited people rising against Jewish imperialism. However, there is an important distinction to be drawn between what the Nazis felt and perceived in their paranoid visions and the reality of the situation: Jews, whether German Jews or Eastern European Jews, were not organized into a movement to colonize and exploit Germany, and if the Nazis felt as if they were leading a subaltern movement then they were seriously deluded. When Frantz Fanon joined the Algerian resistance against French colonialism he had a right to write a book about "the wretched of the earth" and their revolt against imperialism. ${ }^{7}$ The Nazis had no right to make similar claims as they murdered the Jews of Europe. Thus, imperialism is not a sufficient explanation for the Holocaust or the destruction of the Roma. It cannot account for Nazi ideology and psychopathology.

Finally, in the contemporary world, genocide seems to be less a byproduct of imperialism and colonialism than of ethnic nationalism and the global spread of the democratic nation state. Indeed, some of the worst instances of genocide, as in Nigeria, Cambodia, Rwanda, Sudan, and the Congo, have occurred not when these areas were under colonial rule, but when they were supposedly liberated by nationalist movements.

Such movements often privileged one ethnic group over another in a culturally plural context, leading to ethnic conflict and genocide. Although imperialism and colonialism may have inadvertently created some of the conditions that later led to genocide, it was often its opponents, and not the imperial state as such, that committed mass murder. ${ }^{8}$ In some noted instances nationalist movements that had been previously opposed to colonialism and imperialism, once in power, turned against groups in their own society and committed genocide.

The thesis that all genocide can be traced back to imperialism and colonialism is flawed. Indeed, many instances of genocide can be traced directly to such causes, but some important instances cannot. It would seem that genocide, like murder, occurs in many contexts for many reasons, and these need to be investigated from a comparative historical perspective before we can arrive at a convincing explanation of types of genocide, including imperialist genocide.

\section{Victims and Survivors}

When genocide scholars take down the testimony of victims and survivors or read memoirs, they are likely to confront details of brutality, depravity, and horror. Perhaps this explains one of the psychological obstacles to including victim and survivor testimonies. I know that was true for me when I wrote Revolution and Genocide, and it still is. However, there are scholars who have argued that victim and survivor testimony is deeply flawed and should be avoided in historical explanations. Such scholars purposely avoid basing their analyses on victim and survivor accounts or even referring to them. I have chosen Raul Hilberg's The Destruction of the European Jews and Scott Straus's The Order of Genocide as two illustrative cases. ${ }^{9}$ I have done so because they are justly praised, excellent works, exemplary studies of perpetrator behavior, spanning two generations and two paradigmatic instances of genocide. Yet, both neglect victim and survivor testimonies.

In the preface to his magisterial history of the Holocaust, Hilberg makes clear that his is going to be a study of the perpetrators and their collaborators, not of the victims: 
We shall not dwell on Jewish suffering, nor shall we explore the social characteristics of ghetto life or camp existence. Insofar as we may examine Jewish institutions, we will do so primarily through the eyes of the Germans: as tools which were used in the destruction process. ${ }^{10}$

Although in the preface he had announced that he would not discuss the victims, some 600 pages later Hilberg does just that in a brief section labeled "Victims." 11 As a counterpoint to the brilliant institutional analysis of the Nazis that had gone beforehand, Hilberg's account of the motivations and behavior of the Jewish victims is a superficial failure.

His argument is that the Nazi success in killing millions of Jews so quickly and relatively easily derived in large part from Jewish passivity, lack of physical resistance, and complicity in their own destruction. He finds an explanation for this apparently puzzling behavior in the cultural conditioning of Jews who had survived many years of oppression in European ghettos from the Middle Ages onward by becoming weaned from violent resistance and toward accommodation with their persecutors. They took the Nazis to be the latest in a long line of oppressors and reverted to traditional modes and strategies of compliance that played right into their killers' plans.

This is a kind of psychocultural reductionism that Hilberg wisely avoids when discussing the German perpetrators. When it comes to the Jewish victims, however, he completely neglects contemporary developments and differentiation in Jewish culture, religion, class structure, nationality, and institutional frameworks that created deep fissures among Jews and left them deeply divided at the moment of their gravest peril. For example, when it comes to Poland, he neglects the rise of a Polonized secular Jewish middle class and an active working class that had broken with medieval traditions and mores. There is no discussion of the socialist Bund, Jews in the Polish Communist Party, or the various branches of the Zionist movement, all of which were in conflict with each other and with religious parties such as Agudat Israel.

He hardly notes that in no occupied country were the Jews organized or united. Nor were they armed or led by persons with military experience who could organize armed resistance. He dismisses the Warsaw Ghetto Rebellion by noting how few were the German casualties, but he neglects to see how extraordinary it was for a starved, persecuted, terrified, and fragmented collectivity-not a people-to launch a revolt against insurmountable odds in the first place.

Finally, he completely overlooks the Zionist movement and the founding of modern Israel. He cannot possibly explain how it is that the same generation of Jews that had supposedly been conditioned by centuries of ghetto culture and oppression to be so passive and accommodating to persecutors was able to organize a modern state and successfully resist with military force the Arab invasion of 1948-three years after the end of World War II.

Hilberg's analysis of victim and survivor motivation and behavior will not do, but more importantly, by neglecting victim testimonies, his perspective, methodology, and choices limit what he can say about German behavior, the subject of his study. For instance, Hilberg can neither describe nor document the excesses of cruelty practiced by perpetrators in the roundups, transport, and killing operations. ${ }^{12}$ Such excesses against women and children in particular need to be documented and explained. Why, if the perpetrators wanted to destroy the Jews, did they not simply kill them? Why did they expend so much seemingly unnecessary effort in torturing and humiliating their victims, often going beyond their police and military orders? What ideological and/or psychic needs did such excess cruelty satisfy? Such questions 
are most likely to arise from victim/survivor testimonies, not from the self-serving documents and testimonies of the perpetrators.

With some notable exceptions, most Holocaust and genocide scholars have followed Hilberg's path. ${ }^{13}$ They too have purposely focused on the perpetrators and collaborators, assuming that understanding their motives and actions did not entail talking to survivors or studying extant accounts left by victims. An implicit assumption for such scholars is that victim history and testimony is not essential to an explanation of genocide. A recent case in point is Scott Straus's important study of the Rwandan Genocide. ${ }^{14}$

Straus's singular contribution to the discussion of the Rwandan Genocide is based on his interviews with 210 Hutu prisoners who had been incarcerated in fifteen different prisons and who had confessed to active participation in the genocide of 1994. From these interviews he concludes that the perpetrators of the genocide were not driven by ethnic hatred or racialist ideology, as others have suggested, but by obedience to government authority and fear of Tutsi reprisals in wartime.

That fear had been engendered by the Rwanda Patriotic Front (RPF) invasion of Rwanda in 1990, wherein a guerilla army led by Tutsi, originating from Uganda, invaded Rwanda and threatened to establish a new regime. By a process that Straus labels "ethnic categorization" all Tutsi living in Rwanda, even those far from the front, were labeled by the government, as well as by most ordinary Hutu, as being in league with the RPF and therefore as mortal enemies that had to be eliminated:

Ethnic and racial categories preexisted the genocide, and awareness of those categories was widespread and resonant in Rwandan society.... But the switch that led many ordinary Rwandans with little apparent preexisting hatred to categorize Tutsis as dangerous "enemies" happened only in war and only after the state made that claim. ${ }^{15}$

What is methodologically striking about this study is that it is based only on perpetrator testimony, which may be self-serving and self-exculpatory, and that not a single Tutsi survivor was interviewed for this book. Apparently Straus reckoned that such survivor testimony was immaterial to explaining the motives and behavior of Hutu perpetrators. However, if fear and hatred of Tutsi was primarily engendered by the invasion of the RPF in 1990, how does Straus explain the extensive violence against the Tutsi that started with the Revolution of 1959 and recurred again in 1962-1964 and 1973 and subsequently led to the mass flight of Tutsi to neighboring countries, including Uganda from where the RPF originated?

Straus may not have wanted to interview Tutsi survivors, but he had the responsibility to account for the work of other writers who did. Chief among them is Philip Gourevitch, who describes in disturbing detail the pervasive racial hatred and persecution that ordinary Tutsi experienced on a daily basis years prior to the genocide. ${ }^{16}$ Indeed, in 2001, at a conference in Kigali organized by Ibuka, a Tutsi survivors organization, speaker after speaker recounted how the genocide of 1994 had started in 1959 when Hutu leaders had organized a Hutu ethnocracy and commenced to persecute the Tutsi minority. ${ }^{17}$

Thus far, my critique of scholars who neglect victim and survivor testimonies has been largely methodological. The argument is not that genocide studies should be based only on victim testimonies. It is a plea that victim narratives be included in a process of triangulation that juxtaposes them to perpetrator and bystander testimonies. The history that emerges from such a triangulation may be less neat, but it may be more accurate. Finally, genocide is not only about killing people. It is also about seizing their property, destroying their culture, denying their memories, and silencing their 
voices. It is incumbent on us as genocide scholars to give voice to the victims and not to cooperate, even if inadvertently, with their persecutors.

In this article I have focused on three problem areas, but I have necessarily neglected many other important topics that need to be discussed in an assessment of genocide studies. Among these are the extraordinary evolution of international human rights law, on the one hand, and the efforts to devise methods to prevent genocide, on the other hand. Violence persists, but so does our commitment to understand its causes and to prevent its damages.

\section{Notes}

1. This section derives from Robert Melson, "The Armenian Genocide as Precursor and Prototype of Twentieth Century Genocide," in Is the Holocaust Unique? Perspectives on Comparative Genocide, ed. Alan S. Rosenbaum (Boulder, CO: Westview Press, 1996), 87-99. I thank Mr. George Shirinian for his comments.

2. See Robert Melson, Revolution and Genocide: On the Origins of the Armenian Genocide and the Holocaust (Chicago: University of Chicago Press, 1992/1996).

3. A. Dirk Moses, ed., Empire, Colony, and Genocide: Conquest, Occupation, and Subaltern Resistance in World History (New York: Berhahn, 2008); Robert Melson, review of Empire, Colony, and Genocide, ed. Moses, Journal of World History 20, no 3 (2009): 463-66.

4. Moses, Empire, Colony, and Genocide, ix.

5. The Nazis distinguished between German Roma, whom they labeled "Sinti," but this is not a distinction that Roma make. See Ian Hancock, "Roma: Genocide of Roma in the Holocaust," in Encyclopedia of Genocide, ed. Israel W. Charny (Santa Barbara, CA: ABCCLIO, 1999), 501-508.

6. David Furber and Wendy Lower, "Colonialism and Genocide in Nazi Occupied Poland and Ukraine," in Moses, Empire, Colony, and Genocide, 372-402.

7. Frantz Fanon, The Wretched of the Earth (New York: Grove Press, 1963).

8. Robert Melson and Howard Wolpe, "Modernization and the Politics of Communalism: A Theoretical Perspective," The American Political Science Review LXIV (1970): 1112-30.

9. Raul Hilberg, The Destruction of the European Jews (Chicago: Quadrangle, 1961); Scott Straus, The Order of Genocide: Race, Power, and War in Rwanda (Ithaca: Cornell University Press, 2006).

10. Hilberg, The Destruction of the European Jews, v.

11. Ibid., 662-69.

12. See Daniel Jonah Goldhagen, Hitler's Willing Executioners: Ordinary Germans and the Holocaust (New York: Knopf, 1996), 376-415. Documenting such "excess cruelty" is a strength of this controversial book. Unfortunately, Goldhagen falls into a similar psychocultural reductionist trap when discussing the German perpetrators as Hilberg does in discussing the Jewish victims. He views the Germans as motivated by "eliminationist anti-Semitism," a murderous ideology embedded in German culture in the same way that Hilberg views the Jews as in the grip of ghetto mentality and passivity. Each scholar fails to view his subjects as multifaceted and reduces their behavior to one overriding factor.

13. A Holocaust scholar who has made a point of integrating victim accounts into his history is Saul Friedlander: "The present study will attempt to convey an account in which Nazi policies are indeed the central element, but in which the ... victims' attitudes, reactions, and fate are no less an integral part of this unfolding history." See Saul Friedlander, Nazi Germany and the Jews (New York: Harper Collins, 1997), 2.

14. Straus, The Order of Genocide.

15. Ibid., 225.

16. See Philip Gourevitch, We Wish to Inform You that Tomorrow We Will Be Killed with Our Families: Stories from Rwanda (New York: Farrar, Straus, and Giroux, 1998).

17. Ibuka Conference, Kigali, 2 November 2001. I attended and participated at this conference. 